\title{
EVALUASI TARGET DAN REALISASI PENCAPAIAN PAJAK DAERAH PADA BADAN PENDAPATAN DAERAH PROVINSI SULAWESI UTARA
}

\author{
Eka A. Takahindangen ${ }^{1}$, Jenny Morasa $^{2}$, Treesje Runtu ${ }^{3}$ \\ ${ }^{1,2,3}$ Fakultas Ekonomi dan Bisnis, Jurusan Akuntansi, Universitas Sam Ratulangi, Jl. Kampus Bahu, Manado, \\ 95115, Indonesia \\ E-mail : eka23takahindangen@gmail.com
}

\begin{abstract}
Tax is the main source of state revenue. According to Law No. 28 of 2009 concerning PDRD, regional taxes are mandatory for regions that are owed by individuals or bodies related to legislation, by not obtaining direct imbalances and being used for regional needs for the greatest prosperity of the people. The regional government has agreed to collect regional taxes in order to contribute to the regions to increase the ability of funds in their regions. The purpose of this study is to find out the desired targets motorized vehicles, land tax air tax and percentage of motor vehicle tax, name transfer tax, motor vehicle fuel tax, surface water tax and cigarette tax in the North Sulawesi Provincial Revenue Agency for 2014-2017 have been efficient and effective in North Sulawesi Province. The data analysis method used in this study is descriptive. The results of the analysis of Realization of Regional Taxes in North Sulawesi increase every year, in 2014-2017 the highest income tax is cigarette tax. The results of this study were issued by the regional government of North Sulawesi Province further authorizing the District / City Government to work and be responsible for working in accordance with the duties and functions of administering taxes from the community.
\end{abstract}

Keywords: Local tax

\section{PENDAHULUAN}

Sumarsan (2017:3), Pajak adalah peralihan kekayaan dari pihak rakyat kepada kas negara untuk membiayai public saving yang merupakan sumber utama untuk membiayai publik investmen. Sejalan dengan penjelasan tersebut, UU No 28 tahun 2009 tentang PDRD, mempertegas pengertian pajak dalam tataran pemerintah yang lebih rendah, sebagai berikut: Pajak daerah adalah kontribusi wajib kepada daerah yang terutang oleh orang pribadi atau badan yang bersifat memaksa berdasarkan undang-undang, dengan tidak mendapatkan imbalan secara langsung dan digunakan untuk keperluan daerah bagi sebesar-besarnya kemakmuran rakyat. Pajak merupakan sumber utama penerimaan Negara. Tanpa pajak di masyarakat perekonomian Negara tidak bisa berjalan dengan baik.

Sulawesi utara merupakan salah satu dari 7 provinsi kepulauan yang terdiri dari 258 Pulau, dan secara administrasi Sulawesi utara memiliki 15 Kabupaten dan kota yang diantaranya memiliki sumber pendapatan daerah yang cukup baik. Menurut data APBD Provinsi Sulawesi utara secara keseluruhan penerimaan utama pemerintah daerah yaitu Pendapatan asli daerah cenderung menurun sejak tahun 2014-2017, tahun 2014 proporsi PAD sebesar $40.40 \%$ dan tahun 2015 proporsinya turun hingga $38 \%$.

Pemerintah daerah telah diizinkan untuk memungut sejumlah pajak daerah dalam rangka memberi peluang kepada daerah untuk bisa menggali secara maksimal sumber dana yang ada di daerahnya, dengan memperhatikan kondisi ekonomi dan social daerah serta unsur legalitasnya. Hal ini dilakukan agar daerah-daerah dapat mengurus rumah tangganya sendiri secara bertanggung jawab. Otonomi daerah telah membawa banyak perubahan dalam sistem pemerintahan Indonesia, jika dahulu daerah bersifat pasif maka sekarang daerah dituntut untuk aktif dalam mengelola dan mengembangkan daerahnya. Oleh karena itu, daerah 
berlomba-lomba meningkatkan sumber pendapatannya dengan mengenakan berbagai pajak daerah yang memang menjadi kewenangannya.

\section{TINJAUAN PUSTAKA}

Akuntansi. Kartikahadi et al. (2016:3), akuntansi adalah suatu sistem informasi keuangan, yang bertujuan untuk menghasilkan dan melaporkan informasi yang relevan bagi berbagai pihak yang berkepentingan. Sedangkan menurut Ismail (2014:2), akuntansi dapat diartikan sebagai seni dalam melakukan pencatatan, penggolongan, dan pengikhtisaran, yang mana hasil akhirnya tercipta sebuah informasi seluruh aktivitas keuangan perusahaan.Akuntansi adalah proses identifikasi, pencatatan, dan pengkomunikasian keadaan ekonomi suatu perusahaan kepada pihak-pihak yang berkepentingan. Akuntansi merupakan satu kesatuan sistem informasi pemrosesan data sehingga menghasilkan laporan keuangan yang menggambarkan keadaan perusahaan. Kieso et al (2016:2) pengertian akuntansi adalah "Accounting consist of the basic activities-it identifies, records, and communicates the economic events of an organization to interestusers".

Akuntansi Perpajakan. Pajak adalah Iuran rakyat kepada kas Negara berdasarkan UU (yang dapat dipaksakan) dengan tidak mendapat jasa-timbal (kontraprestasi), yang langsung dapat ditunjukan dan yang digunakan untuk membayar pengeluaran umum. Muljono (2015:2) akuntansi pajak adalah bidang akuntansi yang berkaitan dengan perhitungan perpajakan, yang mengacu pada peraturan, undang-undang dan aturan pelaksanaan perpajakan.

Pajak Daerah. Mardiasmo (2016:1) menyatakan bahwa pajak adalah iuran rakyat kepada kas Negara berdasarkan undang-undang (yang dapat dipaksakan) dengan tiada mendapat jasa timbal (kontraprestasi) yang langsung dapat ditunjukan dan yang digunakan untuk membayar pengeluaran umum. Berdasarkan Undang-undang No 28 Tahun 2007 "Pajak adalah Kontribusi wajib kepada Negara yang terutang oleh pribadi atau badan yang bersifat memaksa berdasarkan undang-undang dengan tidak mendapatkan imbalan secara langsung dan digunakan untuk keperluan negara bagi sebesar-besarnya kemakmuran rakyat". Suhartono (2015:8) dari definisi pajak menurut undang-undang No 28 Tahun 2007 tersebut terdapat 5 unsur yang terkandung dalam pengertian pajak, antara lain: (1) kontribusi wajib/kewaajiban kepada Negara; (2) kewajiban yang dapat dipaksakan, kalau tidak dipenuhi akan dikenakan sanksi; (3) dipungut berdasarkan undang-undang; (4) tidak ada imbal jasa (kontra prestasi) yang langsung dapat ditunjuk; dan (5) dipungut oleh/digunakan utuk keperluan Negara.

a). Fungsi Pajak. Resmi (2014:3) terdapat dua fungsi pajak yaitu sebagai berikut: Fungsi Budgetair (Sumber Keuangan Negara) Pajak mempunyai fungsi budgetair artinya pajak merupakan salah satu sumber penerimaan pemerintah untuk membiayai pengeluaran baik rutin maupun pembangunan. Sebagai sumber keuangan negara, pemerintah berupaya memasukan uang sebanyak-banyaknya untuk kas negara.

b). Jenis Pajak. Mardiasmo (2016,27), jenis pajak dikelompokan menjadi 3 bagian yaitu :

1. Menurut Golongan

- Pajak Langsung, yaitu pajak yang harus dipikul sendiri oleh wajib pajak dan tidak dapat dibebankan atau dilimpahkan kepada orang lain, contohnya adalah Pajak Penghasilan $(\mathrm{PPh})$.

- Pajak Tidak Langsung, yaitu pajak yang pada akhirnya dapat dibebankan atau dilimpahkan kepada orang lain, contohnya adalah Pajak Pertambahan Nilai (PPN).

2. Menurut Sifat

- Pajak subjektif, pajak yang berpangkal atau berdasarkan pada subyeknya, dalam arti memperhatikan keadaan diri wajib pajak. Contoh: Pajak Penghasilan (PPh). 
- Pajak Objektif, pajak yang berpangkal pada obyeknya, tanpa memperhatikan keadaan diri wajib pajak. Contoh: Pajak Pertambahan Nilai (PPN) dan Pajak Penjualan Atas Barang Mewah (PPnBM).

3. Menurut Lembaga pemungutan

- Pajak Pusat, yaitu pajak yang dipungut oleh pemerintah pusat dan digunakan untuk membiayai rumah tangga negara. Contoh: Pajak Penghasilan (PPh), Pajak Pertambahan Nilai (PPN, dan Pajak Penjualan Atas Barang Mewah (PPnBM), Pajak Bumi dan Bangunan (PBB), dan Bea Materai.

- Pajak Daerah, yaitu pajak yang dipungut oleh pemerintah daerah dan digunakan untuk membiayai rumah tangga daerah. Pajak daerah terdiri atas: Pajak Provinsi, contoh: pajak kendaraan bermotor dan pajak bahan bakar kendaraan bermotor. Pajak Kabupaten, contoh: pajak hotel, pajak restoran, dan pajak hiburan.

Ciri-ciri Pajak. Resmi (2016:2), ciri-ciri pajak adalah sebagai berikut: (1) pajak dipungut berdasarkan atau dengan kekuatan undang-undang serta aturan pelaksanaannya; (2) dalam pembayaran pajak tidak dapat ditunjukkan adanya kontraprestasi individual oleh pemerintah; (3) pajak dipungut oleh negara, baik pemerintah pusat maupun pemerintah daerah; dan (4) pajak diperuntukkan bagi pengeluaran-pengeluaran pemerintah yang bila dari pemasukannya masih terdapat surplus, digunakan untuk membiayai public investment. Undang-Undang No 28 Tahun 2009 pajak kabupaten dan kota dibagi menjadi beberapa sebagai berikut:

1. Pajak Provinsi

- Pajak Kendaraan Bermotor dan Kendaraan di atas air. Pajak kendaraan bermotor adalah pajak atas kepemilikan dan/atau penguasa kendaraan bermotor. Kendaraan bermotor adalah semua kendaraan yang beroda beserta gandengannya yang digunakan disemua jenis jalan darat, dan digerakan oleh peralatan teknik berupa motor atau peralatan lainnya yang berfungsi untuk merubah suatu sumber daya energy tertentu menjadi tenaga gerak kendaraan bermotor yang bersangkutan, termasuk alatalat berat dan alat-alat besar yang dalam operasinya menggunakan roda dan motor dan tidak melekat secara permanen serta kendaraan bermotor yang dioperasikan di air.

- Bea Balik Nama Kendaraan Bermotor dan Kendaraan di atas air. Bea balik nama kendaraan bermotor adalah pajak atas penyerahan hak milik kendaraan bermotor sebagai akibat perjanjian dua pihak atau perbuatan sepihak atau keadaan yang terjadi karena jual beli, tukar menukar, hibah, warisan atau pemasukan dalam badan usaha.

- Pajak Bahan Bakar Kendaraan Bermotor. Pajak bahan bakar kendaraan bermotor adalah pajak atas penggunaan bahan bakar kendaraan bermotor.Bahan bakar kendaraan bermotor adalah semua jenis bahan bakar cair atau gas yang digunakan untuk kendaraan bermotor.

- Pajak Pengambilan dan Pemanfaatan Air Bawah Tanah dan Air Permukaan. Pajak bahan bakar kendaraan bermotor adalah pajak atas penggunaan bahan bakar kendaraan bermotor.Bahan bakar kendaraan bermotor adalah semua jenis bahan bakar cair atau gas yang digunakan untuk kendaraan bermotor.

- Pajak Rokok. Pajak rokok adalah pajak atas pemungutan cukai rokok yang dipungut oleh pemerintah pusat. Yang dimaksud dengan cukai adalah pungutan negara yang dikenakan terhadap barang-barang tertentu yang mempunyai sifat atau karakteristik yang ditetapakan dalam Undang-Undang Cukai.

2. Pajak Kota/Kabupaten, yang terdiri dari: Pajak Hotel, Pajak Restoran, Pajak Hiburan, Pajak Reklame, Pajak Penerangan Jalan, Pajak Pengambilan Bahan Galian Golongan, Pajak Parkir, Pajak Air Tanah, Bea Perolehan Hak Atas Tanah dan Bangunan (BPHTB), Pajak Sarang Burung Wallet, dan Pajak Bumi dan Bangunan Perdesaan dan Perkotaan. 
Sistem Pemungutan Pajak Daerah. Pemungutan pajak daerah saat ini menggunakan tiga sistem pemungutan pajak, yaitu Dibayar sendiri oleh wajib pajak, ditetapkan oleh kepala daerah dan atau dipungut oleh pemungut pajak. Pemungutan pajak daerah dimungkinkan kerja sama dengan pihak ketiga dalam proses pemungutan pajak, antara lain percetakan formulir perpajakan, pengiriman surat kepada wajib pajak dan penghimpunan data objek dan subjek pajak.

Kebijakan Pemerintah Menyusun Target APBD khususnya Pendapatan asli daerah. Peraturan menteri dalam negeri Nomor 22 Tahun 2011 menjelaskan dengan jelas bahwa untuk menentukan target pajak daerah yaitu dengan melihat kondisi perekonomian yang terjadi pada tahun-tahun sebelumnya, perkiraan pertumbuhan ekonomi pada tahun sebelumnya dan realisasi penerimaan PAD tahun sebelumnya, serta ketentuan peraturan perundang-undangan terkait serta kebijakan penganggaran yang tidak memberatkan masyarakat dan dunia usaha.

\section{METODE PENELITIAN}

Jenis penelitian. Jenis penelitian yang digunakan adalah penelitian deskriptif. Penelitian ini difokuskan pada perhitungan persentasi target dan realisasi penerimaan pajak daerah.Tempat penelitian dilakukan di Kantor Badan Pendapatan Daerah Provinsi Sulawesi Utara, Jalan 17 Agustus No.69 Teling Atas Kecamatan Wanea. Waktu penelitian sejak bulan April 2019 sampai selesai. Data kuantitatif, juga dapat diartikan sebagai suatu metode penelitian dengan landasan pada filsafat positivism, digunakan untuk meneliti populasi atau sampel (Sugiyono 2018:20). Teknik yang digunakan untuk memperoleh data dengan melaksanakan studi lapang adalah Interview/wawancara dilaksanakan dengan melakukan tanya jawab langsung terhadap pihak-pihak yang bersangkutan dengan Laporan Target dan Realisasi Pencapaian Pajak daerah guna mendapatkan data dan keterangan yang berlandaskan pada tujuan penelitian dan dokumen dilakukan dengan melakukan pengumpulan data-data dan dokumen berupa Laporan Target dan Realisasi Pencapaian Pajak Daerah Tahun 20142017 serta Laporan terkait dengan Penelitian.

Metode dan Proses Analisis. Metode analisis data yang digunakan adalah deskriptif. Deskriptif artinya penelitian dimulai dengan mengumpulkan dan menyaring seluruh keterangan yang masuk secara menyeluruh dan detail kemudian diuraikan sehingga diperoleh gambaran yang jelas. Selanjutnya mengevaluasi target dan prentasi realisasi pajak daerah pada Badan Pendapatan Daerah Sulawesi Utara tahun 2014-2017, sehingga dapat ditarik suatu kesimpulan. Prosedur penelitian dalam penelitian ini adalah sebagai berikut :

- Pengumpulan data penelitian yaitu selama 4 tahun periode 2014 - 2017

- Mengolah data Laporan Target dan Realisasi Pencapaian Pajak Daerah tahun 2014-2017 pada Badan Pendapatan Daerah Provinsi Sulawesi Utara.

\section{HASIL PENELITIAN DAN PEMBAHASAN}

Gambaran Umum Objek Penelitian. Dinas Pendapatan Daerah Provinsi Sulawesi Utara dibentuk pada Tahun 1962 dengan nama Kantor Pajak, yang saat itu merupakan bagian dari pemerintah Daerah Tingkat I Sulawesi Utara-Tengah. Pada Tahun 1964 seiring dengan terbentuknya Daerah Tingkat I Sulawesi Utara dan Perkembangan organisasi, berubah menjadi Kantor Inspeksi Pajak. Seiring dengan perkembangan organisasi, pada Tahun 1984 Kantor Inspeksi Pajak berubah menjadi Dinas Pajak dan Pendapatan. Dengan ditetapkannya UU No.18 Tahun 1984 tentang Pajak Daerah dan Retribusi yaitu Pajak Kendaraan Bermotor, Bea Balik Nama Kendaraan Bermotor, Pajak Bahan Bakar Kendaraan Bermotor, dan Retribusi Daerah. Pada tahun 2003, Dinas Pajak dan Pendapatan diganti menjadi Dinas Pendapatan berdasarkan Peraturan Daerah No. 23 Tahun 2003. Saat itu Dinas Pendapatan disamping memiliki 5 UPTD, juga memiliki 4 kantor Samsat Pembantu yaitu Amurang, 
Airmadidi, Tomohon dan Talaud, seiring dengan terbentuknya daerah otonom Kab. Minahasa

Selatan, Kab. Minahasa Utara, Kota Tomohon dan Kab. Kepl. Talaud.

Pada tahun 2011 ditetapkan lagi 7 UPTD baru yaitu Talaud, Sitaro, Bolmong, Mitra, Boltim, Bolsel dan Bolmut seiring dengan berdirinya daerah otonom baru di Provinsi Sulawesi Utara sehingga Dipenda memiliki 15 UPTD dan 4 Samsat Pembantu. Pada tahun 2007 Dinas Pendapatan Daerah berubah menjadi Badan Pengelola dan Retribusi Daerah, Kepala Badan Pengelola Pajak dan Retribusi Daerah, Kepala Badan dipercayakan Kepada Olvie Atteng, SE, M.Si tepatnya pada tanggal 3 Januari 2016 dan pada Januari tahun 2019 Badan Pengelola dan Retribusi Daerah berubah menjadi Badan Pendapatan Daerah Provinsi Sulawesi Utara sampai dengan sekarang.

\section{Visi dan Misi}

Visi : Terdepan Dalam Pengelolaan Pendapatan Daerah dan Pelayanan Prima.

Misi : Untuk mendukung Visi dimaksud, juga telah ditetapkan Misi Badan Pengelola Pajak dan Retribusi Daerah sebagai berikut:

1. Mengembangkan kebijakan pendapatan daerah yang dapat di terima masyarakat, partisipatif, bertanggungjawab dan berkelanjutan.

2. Mewujudkan pelayanan publik yang prima (exellen service) terpercaya, transparan dan akuntabel.

3. Mewujudkan sumberdaya manusia aparatur yang berdedikasi, integritas tinggi dan professional.

4. Membangun sistem kelembagaan yang kompetensi.

\subsection{Hasil Penelitian}

Berdasarkan penelitian yang telah dilakukan pada Badan Pendapatan Daerah Provinsi Sulawesi Utara, diperoleh hasil penelitian target dan realisasi penerimaan pajak daerah Provinsi Sulawesi Utara Tahun 2014-2017, yang terdiri dari pajak kendaraan bermotor, bea balik nama kendaraan bermotor, pajak bahan bakar kendaraan bermotor, pajak air permukaan, dan pajak rokok. Realisasi pendapatan Pajak Daerah di Sulawesi Utara sudah mampu mencapai target dibandingkan tahun-tahun sebelumnya. Untuk lebih jelasnya mengenai hasil penelitian pajak daerah tersebut dapat dilihat pada Tabel 1 dibawah ini.

Tabel 1. Hasil Penelitian Target dan Realisasi Pajak Daerah pada Badan Pendapatan Daerah Provinsi Sulawesi Utara Tahun 2014-2017

\begin{tabular}{clcrrrr}
\hline No & Uraian & Tahun & \multicolumn{1}{c}{ Target } & \multicolumn{1}{c}{ Realisasi } & \multicolumn{1}{c}{ Selisih } & Persentasi \\
\hline 1 & Pajak Kendaraan & 2014 & 243.950 .232 .588 & 234.640 .571 .263 & 9.309 .661 .325 & $96,18 \%$ \\
& bermotor & 2015 & 269.028 .063 .820 & 260.975 .957 .735 & 8.052 .106 .085 & $97,01 \%$ \\
& & 2016 & 255.318 .065 .000 & 276.185 .514 .989 & $(20.867 .449 .989)$ & $108,17 \%$ \\
& & 2017 & 255.318 .065 .000 & 297.054 .708 .646 & $(9.197 .368 .646)$ & $103,20 \%$ \\
2 & Bea balik nama & 2014 & $316,452,739,440$ & $282,997,166,250$ & $33,455,573,190$ & $89,43 \%$ \\
& Kendaraan ber- & 2015 & $322,210,479,540$ & $258,450,399,693$ & $63,760,079,847$ & $80,21 \%$ \\
& motor & 2016 & $258,144,600,000$ & $266,560,768,805$ & $(8,416,168,805)$ & $103.26 \%$ \\
& & 2017 & $278,539,160,000$ & $295,485,760,328$ & $(16,946,600,328)$ & $106,08 \%$ \\
3 & Pajak Bahan & 2014 & $183,336,168,000$ & $196,938,425,823$ & $(13,602,257,823)$ & $107,42 \%$ \\
& Bakar kendaraan & 2015 & $220,123,486,640$ & $203,967,373,500$ & $16,156,113,140$ & $92,66 \%$ \\
& bermotor & 2016 & $181,123,486,640$ & $187,366,177,880$ & $(6,242,691,240)$ & $103,45 \%$ \\
& & 2017 & $205,316,400,000$ & $217,589,107,612$ & $(12,272,707,612)$ & $105,98 \%$ \\
4 & Pajak Air & 2014 & $3,229,570,000$ & $1,252,568,300$ & $1,977,001,700$ & $38,78 \%$ \\
& Permukaan & 2015 & $3,239,570,000$ & $1,214,611,310$ & $2,024,958,690$ & $37,49 \%$ \\
& & 2016 & $1,250,000,000$ & $1,074,452,966$ & $175,547,034$ & $85,96 \%$ \\
& & 2017 & $1,610,496,000$ & $1,485,551,430$ & $124,944,570$ & $92,24 \%$ \\
5 & Pajak Rokok & 2014 & $96,000,000,000$ & $69,377,472,983$ & $26,622,527,017$ & $72,27 \%$ \\
& & 2015 & $98,560,000,000$ & $112,412,415,261$ & $(13,852,415,261)$ & $114,05 \%$ \\
& & 2016 & $127,900,000,000$ & $107,157,711,896$ & $20,742,288,104$ & $83,78 \%$ \\
& & 2017 & $166,387,500,000$ & $172,272,000,181$ & $(5,884,500,181)$ & $103,54 \%$ \\
\hline
\end{tabular}

Sumber : Hasil penelitian, Data diolah, 2019 


\subsection{Pembahasan}

Evaluasi target dan realisasi Pajak Kendaraan Bermotor. Berdasarkan hasil perhitungan diatas, dapat diketahui bahwa realisasi penerimaan pajak kendaraan bermotor Provinsi Sulawesi Utara Tahun 2014-2017, dimana pada tahun 2014 target penerimaan pajak adalah Rp 243.950.232.588 dan realisasi penerimaan pajak sebesar Rp 234.640.571.263 atau 96.18\% tidak mencapai target penerimaan sebesar Rp 243.950.232.588. Pada tahun 2015 terjadi kenaikan target dan realisasi penerimaan. Target naik menjadi Rp menjadi sebesar Rp 260.975.957.735 atau 97.01 \% tidak mencapai target penerimaan sebesar Rp 269.028.063.820. Setelah dua tahun berturut-turut tidak mencapai target Di tahun 2016 meningkat sebesar Rp 276.185.514.989 atau sebesar 108.17 \% melampaui pencapaian target penerimaan sebesar Rp 255.318.065.000. ditahun 2017 sebesar Rp 297.054.708.646 atau $103.20 \%$ melampaui pencapaian target penerimaan sebesar Rp 287.857.340.000.

Tabel 2. Target dan Realisasi Pajak Kendaraan Bermotor pada Badan Pendapatan Daerah Provinsi Sulawesi Utara Tahun 2014-2017

\begin{tabular}{cccccc}
\hline No & Tahun & Target & Realisasi & Selisih & Persentasi \\
\hline 1 & 2014 & 243.950 .232 .588 & 234.640 .571 .263 & 9.309 .661 .325 & $96,18 \%$ \\
2 & 2015 & 269.028 .063 .820 & 260.975 .957 .735 & 8.052 .106 .085 & $97,01 \%$ \\
3 & 2016 & 255.318 .065 .000 & 276.185 .514 .989 & $(20.867 .449 .989)$ & $108,17 \%$ \\
4 & 2017 & 255.318 .065 .000 & 297.054 .708 .646 & $(9.197 .368 .646)$ & $103,20 \%$ \\
\hline
\end{tabular}

Sumber : Hasil penelitian, Data diolah, 2019

Evaluasi target dan realisasi Bea Balik Nama Kendaraan Bermotor. Berdasarkan hasil perhitungan diatas, dapat diketahui bahwa realisasi penerimaan pajak bea balik nama kendaraan bermotor Provinsi Sulawesi Utara tahun 2014-2017, dimana pada tahun 2014 realisasi penerimaan pajak sebesar Rp 282.997.166.250 atau 89.43\% tidak mencapai target penerimaan sebesar Rp 316.452.739.440. Pada tahun 2015 mengalami penurunan penerimaan pajak sebesar Rp 258.450.399.693 atau 80.21\% tidak mencapai target penerimaan sebesar Rp 322.210.479.540. setelah 2 tahun berturut-turut tidak mencapai target di tahun 2016 meningkat sebesar $\mathrm{Rp} 266.560 .768 .805$ atau $103.26 \%$ melampaui pencapaian target penerimaan sebesar Rp 258.144.600.000. Di Tahun 2017 meningkat sebesar Rp 295.485.760.328 atau $106.08 \%$ melampaui pencapaian target penerimaan sebesar $\mathrm{Rp}$ 278.539.160.000.

Tabel 3. Target dan Realisasi Bea Balik Nama Kendaraan Bermotor pada Badan Pendapatan Daerah Provinsi Sulawesi Utara Tahun 2014-2017

\begin{tabular}{cccccr}
\hline No & Tahun & Target & Realisasi & Selisih & \multicolumn{1}{c}{ Persentasi } \\
\hline 1 & 2014 & $316,452,739,440$ & $282,997,166,250$ & $33,455,573,190$ & $89,43 \%$ \\
2 & 2015 & $322,210,479,540$ & $258,450,399,693$ & $63,760,079,847$ & $80,21 \%$ \\
3 & 2016 & $258,144,600,000$ & $266,560,768,805$ & $(8,416,168,805)$ & $103.26 \%$ \\
4 & 2017 & $278,539,160,000$ & $295,485,760,328$ & $(16,946,600,328)$ & $106,08 \%$ \\
\hline
\end{tabular}

Sumber : Hasil penelitian, Data diolah, 2019

Evaluasi Target dan Realisasi Pajak Bahan Bakar Kendaraan Bermotor. Berdasarkan hasil perhitungan diatas, dapat diketahui bahwa realisasi penerimaan pajak bahan bakar kendaraan bermotor Provinsi Sulawesi Utara tahun 2014-2017, dimana tahun 2014 realisiasi penerimaan pajak sebesar Rp 196.938.425.823 atau 107.42\% melampaui pencapaian target penerimaan sebesar Rp 183.336.168.000. Pada tahun 2015 turun sebesar Rp 203.967.373.500 atau 92.66\% tidak mencapai target sebesar Rp 220.123.486.640. Tahun 2016 meninkat sebesar Rp 187.366.177.880 atau 103.45\% melampaui pencapaian target 
sebesar Rp 181.123.486.640. Tahun 2017 meningkat sebesar Rp 217.589.107.612 atau $105.98 \%$ melampaui pencapaian target sebesar Rp 205.316.400.000.

Tabel 4. Target dan Realisasi Pajak bahan bakar Kendaraan Bermotor pada Badan Pendapatan Daerah Provinsi Sulawesi Utara Tahun 2014-2017

\begin{tabular}{ccccrr}
\hline No & Tahun & Target & Realisasi & \multicolumn{1}{c}{ Selisih } & \multicolumn{1}{c}{ Persentasi } \\
\hline 1 & 2014 & $183,336,168,000$ & $196,938,425,823$ & $(13,602,257,823)$ & $107,42 \%$ \\
2 & 2015 & $220,123,486,640$ & $203,967,373,500$ & $16,156,113,140$ & $92,66 \%$ \\
3 & 2016 & $181,123,486,640$ & $187,366,177,880$ & $(6,242,691,240)$ & $103,45 \%$ \\
4 & 2017 & $205,316,400,000$ & $217,589,107,612$ & $(12,272,707,612)$ & $105,98 \%$ \\
\hline
\end{tabular}

Sumber : Hasil penelitian, Data diolah, 2019

Evaluasi Target dan Realisasi Pajak Air Permukaan. Berdasarkan hasil perhitungan diatas, dapat diketahui bahwa realisasi penerimaan pajak air permukaan Provinsi Sulawesi Utara tahun 2014-2017 empat tahun berturut-turut tidak mencapai target, dimana pada tahun 2014 realisasi penerimaan pajak sebesar Rp 1.252 .568 .300 atau $38.78 \%$ tidak mencapai target penerimaan sebesar Rp 3.229.570.000. Pada tahun 2015 turun sebesar Rp 1.214.611.310 atau 37.49\% tidak mencapai target penerimaan sebesar Rp 3.239.570.000. Tahun 2016 meningkat sebesar Rp 1.074.452.966 atau 85.96\% tidak mencapai target sebesar Rp 1.250.000.000. Tahun 2017 meningkat sebesar Rp 1.485.551.430 atau $92.24 \%$ tidak mencapai target penerimaan sebesar Rp 1.610.496.000.

Tabel 5. Target dan Realisasi Pajak Air Permukaan pada Badan Pendapatan Daerah Provinsi Sulawesi Utara Tahun 2014-2017

\begin{tabular}{ccccrr}
\hline No & Tahun & Target & Realisasi & \multicolumn{1}{c}{ Selisih } & \multicolumn{1}{c}{ Persentasi } \\
\hline 1 & 2014 & $3,229,570,000$ & $1,252,568,300$ & $1,977,001,700$ & $38,78 \%$ \\
2 & 2015 & $3,239,570,000$ & $1,214,611,310$ & $2,024,958,690$ & $37,49 \%$ \\
3 & 2016 & $1,250,000,000$ & $1,074,452,966$ & $175,547,034$ & $85,96 \%$ \\
4 & 2017 & $1,610,496,000$ & $1,485,551,430$ & $124,944,570$ & $92,24 \%$ \\
\hline
\end{tabular}

Evaluasi Target dan Realisasi Pajak Rokok. Berdasarkan hasil perhitungan diatas, dapat diketahui bahwa realisasi penerimaan pajak rokok Provinsi Sulawesi Utara tahun 20142017, dimana pada tahun 2014 realisasi penerimaan pajak tidak mencapai target sebesar Rp 69.377.472.983 atau 72.27\% dengan target penerimaan pajak sebesar Rp 96.000.000.000. Pada Tahun 2015 realisasi penerimaan pajak naik sebesar Rp 112.412.415.261 atau 114.05\% melampaui pencapaian target sebesar Rp 98.560.000.000. Tahun 2016 kembali tidak mencapai target dengan realisasi penerimaan pajak sebesar $\mathrm{Rp} 107.158 .711 .896$ atau $83.78 \%$ dengan target Rp 127.900.000.000.

Tabel 6. Target dan Realisasi Pajak Rokok pada Badan Pendapatan Daerah Provinsi Sulawesi Utara Tahun 2014-2017

\begin{tabular}{ccrrrr}
\hline No & Tahun & \multicolumn{1}{c}{ Target } & \multicolumn{1}{c}{ Realisasi } & \multicolumn{1}{c}{ Selisih } & \multicolumn{1}{c}{ Persentasi } \\
\hline 1 & 2014 & $96,000,000,000$ & $69,377,472,983$ & $26,622,527,017$ & $72,27 \%$ \\
2 & 2015 & $98,560,000,000$ & $112,412,415,261$ & $(13,852,415,261)$ & $114,05 \%$ \\
3 & 2016 & $127,900,000,000$ & $107,157,711,896$ & $20,742,288,104$ & $83,78 \%$ \\
4 & 2017 & $166,387,500,000$ & $172,272,000,181$ & $(5,884,500,181)$ & $103,54 \%$ \\
\hline
\end{tabular}

Sumber : Hasil penelitian, Data diolah, 2019 
Tahun 2017 realisasi kembali meningkat sebesar Rp 172.272.000.181 atau $103.54 \%$ melampaui pencapaian target sebesar Rp 166.387.500.000. Gambar 1 menyajikan penerimaan pajak daerah tahun 2014 hingga 2017.

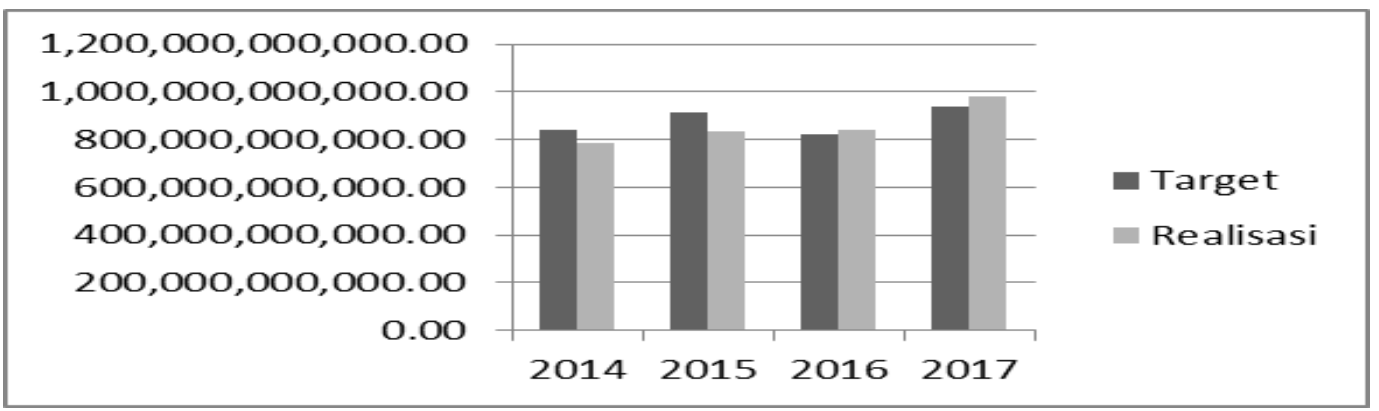

\section{Gambar 1. Pertumbuhan Target dan Realisasi Pajak Daerah pada Badan Pendapatan Daerah Provinsi Sulawesi Utara Tahun 2014-2017 \\ Sumber: Data Diolah, 2019}

Berikut adalah dampak-dampak yang menyebabkan penerimaan pajak daerah mengalami kenaikan dan penurunan selama tahun 2014-2017.

Penerimaan Pajak Kendaraan Bermotor. Berdasarkan evaluasi diatas, pada tahun 2014 dan 2015 penerimaan pajak mengalami penurunan, Sedangkan tahun 2016 dan 2017 penerimaan pajak mengalami peningkatan. Selain itu, pajak kendaraan bermotor di Sulawesi Utara pada tahun 2014-2015 tidak mencapai target sedangkan tahun 2016-2017 mencapai target yang telah ditentukan. Persentase rata-rata realisasi penerimaan pajak kendaraan bermotor yang dipungut oleh Badan Pendapatan Daerah Provinsi Sulawesi Utara tahun 20142017 sebesar 101.14\%. Dari penerimaan pajak kendaraan bermotor yang baik dan terus memenuhi target sangat berpengaruh besar terhadap peningkatan PAD. Dimana penerimaan pajak kendaraan bermotor mampu memberikan kontribusinya untuk meningkatkan PAD. Dari PAD tersebut nantinya akan digunakan atau dianggarkan untuk pembangunan infrastruktur di daerah ataupun pada provinsi.

Penerimaan Bea Balik Nama Kendaraan Bermotor. Berdasarkan evaluasi diatas, dapat dilihat penerimaan pajak bea balik nama kendaraan bermotor selama 4 tahun berturutturut naik. Persentase rata-rata realisasi penerimaan pajak bea balik nama kendaraan bermotor yang dipungut oleh Badan Pendapatan Daerah Provinsi Sulawesi Utara tahun 2014-2017 sebesar $94.75 \%$. Penerimaan bea balik nama kendaraan bermotor tahun 2014 dan 2015 tidak mencapai target karena keterlambatan masyarakat dalam proses pembayaran pajak. Banyak masyarakat yang lupa dengan tanggal jatuh tempo pembayaran pajak. Selain itu karena adanya pengaruh perekonomian melambat secara nasional. Tidak tercapainya target bea balik nama kendaraan bermotor terjadi di semua daerah, bahkan di provinsi lain. Bea balik nama kendaraan bermotor ini merupakan salah satu pajak daerah yang perlu mendapat perhatian. Sebab, pembeli tidak melakukan balik nama kendaraan terhadap kendaraan bekas yang telah dibeli oleh penjual hal ini terjadi karena pembeli takut terkena tarif progresif. Kesamaan lainnya dalam penelitian ini yaitu dengan penelitian yang dilakukan oleh Makaluas (2016) di Dinas Pendapatan Daerah Provinsi Sulawesi Utara, menyatakan bahwa bahwa realisasi penerimaan biaya balik nama kendaraan bermotor mengalami peningkatan pada tahun 2011 sampai dengan tahun 2013, dan mengalami penurunan pada tahun 2014 sampai dengan 2015. Namun meskipun biaya balik nama mengalami penurunan realisasi penerimaan dua tahun terakhir, BBNKB tetap menjadi sumber pendapatan terbesar dalam kurun waktu 5 tahun terakhir pada Pendapatan Asli Daerah Provinsi Sulawesi Utara yakni sebesar 32,77\%. 
Penerimaan Pajak Bahan Bakar Kendaraan Bermotor. Berdasarkan evaluasi diatas, diketahui realisasi penerimaan pajak bahan bakar kendaraan bermotor tahun 20142017 mengalami kenaikan, meskipun di tahun 2015 turun. Pada tahun 2017 merupakan penerimaan tertinggi yaitu sebesar $\mathrm{Rp} 217.589 .107 .612$ atau $105.98 \%$ dengan target penerimaan sebesar Rp 205.316.400.000. Persentase rata-rata realisasi penerimaan pajak bahan bakar kendaraan bermotor yang dipungut oleh Badan Pendapatan Daerah Provinsi Sulawesi Utara tahun 2014-2017 sebesar 102.38 melampaui pencapaian target. Berdasarkan rekapitulasi data per item, pendapatan pajak daerah di dominasi PBBKB. Hal itu masih dipengaruhi tingginya konsumsi BBM, termasuk penggunaan kendaraan pribadi masyarakat yang pertumbuhannya sangat signifikan dalam beberapa tahun terakhir. Hal ini sejalan dengan penelitian yang dilakukan oleh Rahayuanty (2018), menyatakan bahwa realisasi penerimaan pajak bahan bakar kendaraan bermotor tahun 2009-2014 mengalami kenaikan berturut-turut, dan pada tahun 2014 merupakan penerimaan tertinggi yaitu sebesar Rp 3.402.234.134.436,65 atau 119\% dengan target penerimaan sebesar Rp 2.850.000.000.000,00. Pada dasarnya perlu diketahui bahwa di Kalimantan Timur sumber daya alamnya sangat tinggi. Jadi menurunnya penerimaan pajak bahan bakar kendaraan bermotor disebabkan oleh sektor pertambangan khususnya batu bara yang tutup karena anjlok. Untuk meningkatkan pendapatan pajak disektor tersebut, pihak Badan Pendapatan Daerah Provinsi Kalimantan Timur meminta setiap Badan Pendapatan Daerah Kabupaten/Kota juga aktif melakukan pendataan dan pengawasan terhadap pelaku usaha pengguna bahan bakar mengingat selama ini peran tersebut hanya dilakukan oleh Badan Pendapatan Daerah Provinsi Kalimantan Timur.

Penerimaan Pajak Air Permukaan. Berdasarkan evaluasi diatas, dapat dilihat realisasi penerimaan pajak air permukaan pada Badan Pendapatan Daerah Provinsi Sulawesi Utara tahun 2014-2017 mengalami pertumbuhan yang naik-turun dan pajak air permukaan ini merupakan penerimaan pajak terendah dibandingkan dengan jenis pajak lainnya dengan realisasi penerimaan paling tinggi pada tahun 2014 sebesar $\mathrm{Rp} 1.485 .551 .430$ atau $92.24 \%$ dan realisasi penerimaan paling rendah pada tahun 2015 sebesar $\mathrm{Rp}$ 1.214.611.310 atau $37.49 \%$. Persentase rata-rata realisasi penerimaan pajak air permukaan yang dipungut oleh Badan Pendapatan Daerah Provinsi Sulawesi Utara tahun 2014-2017 sebesar 63.62\%. Hal Ini sejalan dengan penelitian yang dilakukan oleh Waani (2016) pada Dinas Pendapatan Daerah Provinsi Sulawesi Utara, menyatakan bahwa pertumbuhan Pajak Air Permukaan di Provinsi Sulawesi Utara mengalami penurunan dari tahun ke tahun, pertumbuhan tertinggi Pajak Air Permukaan di tahun 2011 sebesar 212.59\% dan pertumbuhan terendah pada tahun 2015 sebesar $37.25 \%$. Tingkat efektivitas penerimaan Pajak Air Permukaan di Provinsi Sulut pada tahun 2011-2015 efektif. Hal tersebut menunjukan bahwa pemerintah Provinsi Sulawesi Utara kurang serius dalam memperhatikan, memanfaatkan, dan mengoptimalkan sumber-sumber penerimaan yang tergolong dalam objek Pajak Air Permukaan serta faktor-faktor yang lain yang mempengaruhi penerimaan Pajak Air Permukaan. Kontribusi Pajak Air Permukaan juga mengalami penurunan dari tahun ke tahun. Hal tersebut disebabkan oleh penurunan efektivitas penerimaan Pajak Air Permukaan dari tahun ke tahun sehingga mengurangi kontribusinya terhadap Pendapatan Asli Daerah Provinsi Sulawesi Utara.

Penerimaan Pajak Rokok. Berdasarkan evaluasi diatas, dapat dilihat realisasi penerimaan pajak rokok pada Badan Pendapatan Daerah Provinsi Sulawesi Utara tahun 20142017, memiliki persentase rata-rata sebesar 93.41\% saja. Dari tahun 2014 sampai tahun 2016 realisasi penerimaan pajak rokok mengalami pertumbuhan naik-turun setiap tahunnya. Hal itu dikarenakan cukai rokok setiap tahunnya mengalami kenaikan yang ditentukan oleh kementrian keuangan pusat. Selain itu juga konsumen rokok semakin tahun semakin bertambah. Jadi otomatis penerimaan pajak rokok juga ikut meningkat setiap tahunnya. 


\section{KESIMPULAN DAN SARAN}

\subsection{Kesimpulan}

Berdasarkan analisis dan pembahasan yang telah diuraikan, maka terdapat beberapa kesimpulan yaitu berdasarkan data dan hasil perhitungan, realisasi penerimaan pajak daerah pada Badan Pendapatan Daerah Provinsi Sulawesi Utara mengalami penurunan pada tahun 2014-2015, dan mengalami kenaikan pada tahun 2016-2017. Pajak kendaraan bermotor pada Badan Pendapatan Daerah Provinsi Sulawesi Utara tahun 2014-2017 realisasi penerimaan pajaknya dari tahun 2014-2017 hanya di tahun 2014 dan 2015 saja yang pertumbuhannya menurun. Selama dua tahun terakhir realisasi penerimaan pajak kendaraan bermotor selalu mencapai target yang ditentukan. Penerimaan pajak kendaraan bermotor yang menurun disebabkan oleh keterlambatan masyarakat dalam proses pembayaran pajak. Karena tidak sedikit masyarakat yang lupa dengan tanggal jatuh tempo pembayaran pajak.

Bea balik nama kendaraan bermotor pada Badan Pendapatan Daerah Provinsi Sulawesi Utara tahun 2014-2017 realisasi penerimaan pajaknya dua tahun berturut-turut yaitu dari tahun 2014-2015 tidak mencapai target. Tetapi setelah memasuki tahun 2016-2017 penerimaan meningkat dan mencapai target yang ditentukan. Bea balik nama kendaraan bermotor ini merupakan salah satu pajak daerah yang perlu mendapat perhatian. Menurunnya dan tidak tercapainya target penerimaan pajak bea balik nama kendaraan bermotor disebabkan realisasi penerimaan pajaknya dipengaruhi oleh faktor kemampuan daya beli masyarakat, perekonomian secara makro dan pertumbuhan investasi daerah.

Pajak bahan bakar kendaraan bermotor pada Badan Pendapatan Daerah Provinsi Sulawesi Utara tahun 2014-2017 realisasi penerimaan pajaknya dari tahun 2014-2017 penerimaan selalu meningkat, tetapi pada tahun 2015 penerimaan tidak mencapai target yang ditentukan. Setelah memasuki tahun 2016-2017 penerimaan meningkat sampai $105.98 \%$ mencapai target yang ditentukan. Hal itu masih dipengaruhi tingginya konsumsi BBM, termasuk penggunaan kendaraan pribadi masyarakat yang pertumbuhannya sangat signifikan dalam beberapa tahun terakhir. Pajak air permukaan pada Badan Pendapatan Daerah Provinsi Sulawesi Utara tahun 2014-2017 realisasi penerimaan pajaknya mengalami peningkatan meskipun selama 4 tahun berturut tidak mencapai target yang ditentukan. Pajak air permukaan ini juga merupakan pajak daerah yang penerimaannya paling rendah. Hal itu dikarenakan pihak Badan Pendapatan Daerah Provinsi Sulawesi Utara hanya memungut pajak air permukaan saja dan perusahaannya juga tidak banyak, maka dari itu penggunaan air permukaan berkurang. Selain itu, Nilai Perolehan Air yang rendah dan tidak ada perubahan.

Pajak rokok pada Badan Pendapatan Daerah Provinsi Sulawesi Utara tahun 20142016 realisasi penerimaan pajaknya mengalami kenaikan setiap tahunnya. Hal itu dikarenakan cukai rokok setiap tahunnya mengalami kenaikan yang ditentukan oleh kementrian keuangan daerah. Selain itu juga konsumen rokok semakin tahun semakin bertambah. Jadi otomatis penerimaan pajak rokok juga ikut meningkat setiap tahunnya. Maka dapat disimpulkan bahwa realisasi pencapaian pajak daerah pada Badan Pendapatan Daerah Provinsi Sulawesi Utara tahun 2014 - 2015 sebagian besar pajak daerah tidak mencapai target sedangkan ditahun 2016 - 2017 mengalami kenaikan dimana sebagian besar pajak daerah sudah mencapai target.

\subsection{Saran}

Adapun saran yang diberikan setelah melakukan penelitian ini adalah Kepada pemerintah pusat agar memberikan kewenangan kepada pemerintah daerah Provinsi Sulawesi Utara yang lebih luas dalam menarik semua pajak di daerah sehingga dapat meningkatkan Pendapatan Asli Daerah, yang selanjutnya kepada pemerintah daerah Provinsi Sulawesi Utara lebih memberi kewenangan pula terhadap Pemerintah Kabupaten/Kota untuk bekerja dan bertanggung jawab dalam bekerja sesuai tugas dan fungsinya mengurus pajak dari masyarakat. 


\section{DAFTAR PUSTAKA}

Kartikahadi, H., Syamsul, R. U. S. M., \& Siregar, S. V. (2016). Akuntansi Keuangan berdasarkan SAK Berbasis IFRS Buku 1. Jakarta: Salemba Empat.

Ismail. (2014). Perbankan Syariah. Jakarta: Kencana.

Kieso, D. E., Weygandt, J. J., \& Warfield, T. D. (2018). Akuntansi Keuangan Menengah Edisi IFRS Volume 2. Jakarta: Salemba Empat

Mardiasmo. (2016). Perpajakan Edisi Revisi Tahun 2016. Yogyakarta: Penerbit Andi.

Muljono. (2015). Hukum Pajak. Yogyakarta: Penerbit Andi.

Makaluas, O. F., \& Tinangon, J. (2016). Analisis Penerimaan Pajak Biaya Balik Nama Kendaraan Bermotor (BBNKB) pada Kantor Dinas Pendapatan Daerah di Provinsi Sulawesi Utara. Jurnal EMBA, 4(2), 013-021. https://ejournal.unsrat.ac.id/index.php/emba/article/view/12467https://ejournal.unsrat. ac.id/index.php/emba/article/view/12467

Peraturan Pemerintah Nomor 28 Tahun 2009 tentang Pajak Daerah dan Retribusi Daerah. Lembaran Negara Republik Indonesia.

Rahayuanti, S., Malisan, L., \& Kusumawardani, A. (2018). Analisis Target dan Realisasi Pajak Daerah. EJournal FEB Unmul, 15(1), 55-66. http://journal.feb.unmul.ac.id/index.php/AKUNTABEL/article/view/2514/329

Resmi, S. (2014). Perjakan Teori dan Kasus Edisi 4. Jakarta: Salemba Empat.

Republik Indonesia. Peraturan Menteri dalam negeri Nomor 22 Tahun 2011 Tentang Pedoman Penyusunan Anggran Pendapatan dan Belanja Daerah Tahun Anggaran 2012.

Sumarsan, T. (2017). Perpajakan Indonesia: Pedoman Perpajakan Lengkap Berdasarkan Undang-Undang Terbaru (Edisi 5). Jakarta : PT.Indeks.

Sugiyono. (2016). Metode Penelitian Kuantitatif, Kualitatif, dan $R \& D$. Bandung : Alfabeta.

Suhartono. (2015). Ensiklopedia Perpajakan. Jakarta: Salemba Empat.

Waani, I. G. K. (2016). Analisis Efektivitas Dan Kontribusi Pajak Air Permukaan Terhadap Penerimaan Pendapatan Asli Daerah Provinsi Sulawesi Utara. Jurnal EMBA, 4(1), 667-675. https://media.neliti.com/media/publications/2937-ID-analisis-efektivitasdan-kontribusi-pajak-air-permukaan-terhadap-penerimaan-pend.pdf

Waluyo, (2017). Akuntansi Pajak. Edisi 6. Jakarta: Salemba Empat. 